\title{
Chapter 5 \\ Researching Climate Change in Their \\ Own Backyard-Inquiry-Based \\ Learning as a Promising Approach \\ for Senior Class Students
}

\section{Sebastian Brumann, Ulrike Ohl and Carolin Schackert}

\begin{abstract}
Inquiry-based learning (IBL) enables students to personally experience climate change, which is often perceived as a rather abstract phenomenon. This article outlines characteristics of the IBL approach and sums up its most important benefits for climate change education. Recent relevant school projects, which address the topic of climate change, are presented. The article then describes main features of a prototypical IBL concept, which is being developed at the Chair of Geography Education at the University of Augsburg. In this project, Bavarian senior class high school students conduct research on the effects of climate change in their immediate surroundings. They work on individually generated study questions using anthropogeographic and physiogeographic research methods. In order to do so, students are led towards a deeper understanding of the regional implications of climate change by working with online learning modules that additionally present adequate research methods. They also present their scientific findings in front of peers, a broader public and climatologists. Finally, first findings of the project portrayed above are discussed.
\end{abstract}

Keywords Climate change education - Inquiry-based learning · Fieldwork • Regional implications of climate change $\cdot$ Complexity

\section{Teaching Climate Change-A Relevant and Challenging Matter}

Current and pressing challenges of global climate change not only require corrective measures by governments and economy but also climate literate behaviour of the individual. Students, in particular, can make climate conscious decisions in areas

\footnotetext{
S. Brumann $(\varangle) \cdot$ U. Ohl · C. Schackert

Chair of Geography Education, University of Augsburg, Augsburg, Germany

e-mail: sebastian.brumann@geo.uni-augsburg.de

U. Ohl

e-mail: ulrike.ohl@geo.uni-augsburg.de

C. Schackert

e-mail: carolin.schackert@geo.uni-augsburg.de
} 
such as personal mobility, holiday destinations, recreational activities, nutrition, consumerism, energy consumption and, partly, housing (Chiari et al. 2016).

Studies have shown that a certain climate literacy, i.e. basic knowledge about climate change as an issue as well as its causes and possible effects, does exist, at least in Central European societies (Chiari et al. 2016). At the same time, there is a frequently described discrepancy between a person's awareness or knowledge of climate change on the one hand and their actions on the other hand: although the risks of climate change are considered relevant, most people do little to counteract it (Renn 2018). A Europe-wide survey showed that especially people below the age of 24 contribute considerably less to climate-conscious behaviour than older groups (European Commission 2014). Personal factors that influence climate literate behaviour and help to explain this discrepancy are diverse. Chiari et al. (2016) illustrate that these factors can be both personal (as for example knowledge, values and attitudes, interests, perceived self-efficacy) and situational (as for example available infrastructure, economic circumstances or social context).

School education, especially geography education, is responsible for contributing to adequate climate change education by positively influencing the above-mentioned factors, as best as educational settings allow. In this context, teaching knowledge of climate change as well as the ability to act sustainably are crucial goals. As already mentioned, it is clear that the dissemination of knowledge alone does not automatically lead to climate literate behaviour. However, knowledge is an essential prerequisite for it. Results from a study by Ranney and Clark (2016) among American citizens are encouraging, as they show that the acceptance for anthropological climate change as well as the willingness to act grew with an understanding of the greenhouse effect. Additionally, these findings could be replicated in another study with German participants (Ranney and Clark 2016).

The didactic challenges that arise in connection with climate change education result in particular from the topic's complexity as well as a perceived temporal and spatial detachment from impacts of climate change.

\section{The Complexity of Climate Change}

Climate change is a complex issue on both a factual and an ethical level, as it is characterised by a tension between numerous interconnected aspects such as economic interests, ecological goals, cultural orientations, social norms and political decisions (Meyer et al. 2018). Approaches from both sciences and humanities are necessary to cover the subject adequately, assess its risks and find viable solutions (Meyer et al. 2018). As another facet of its factual complexity, it is local and global factors that play a role as well. With this in mind, factual complexity is then complemented by an ethical dimension. This becomes visible in the ongoing discussion on climate justice, for example.

In light of these complexities, it is not a surprise that international research in the field of Conceptual Change has uncovered challenges in teaching about climate change. Much of the research conducted shows that students often have wrong, highly persistent conceptions of climate change, especially with regard to the causes of climate change and possible solutions and, to a lesser degree, with respect to the 
impact of climate change (see Felzmann 2018 for a summary). Many children and adolescents mistakenly assume that the ozone hole is the cause of the anthropological greenhouse effect. Furthermore, without further differentiation, students often attribute the greenhouse effect to "emissions" that supposedly destroy the ozone layer. Another common misconception is that of a confined $\mathrm{CO}_{2}$ or greenhouse gas layer in high altitudes (Schuler 2011; Felzmann 2018). Reinfried and Tempelmann (2014) show that scientific misconceptions formed prior to classes on the topic of climate change play a significant role in it. Depending on the characteristics of these scientific misconceptions, they may or may not be modified by learning environments, which are specifically designed to target them. Overall, research has shown that actively formulating and working with misconceptions is more effective than ignoring them (Felzmann 2018).

Attempts to explain the above-mentioned difficulties go beyond the topic's complexity as they also include the fact that, especially to people living in Central Europe, the mechanics of climate change are only perceivable to a small degree. Correspondingly, most people do not have personal experiences with climate change (Renn 2018). According to Reinfried (2007), in this case, many people might fall back on unscientific categories, which might lead to a causal connection of aspects such as the metaphoric term ozone hole, personally perceived temperature fluctuations, conceptions of a greenhouse glass ceiling and self-experienced higher concentrations of near-ground ozone.

\section{Perceived Spatial and Temporal Detachment}

In Central Europe and other regions of the world, the effects of climate change can only be perceived to a small degree, which causes a so-called "psychological distancing", i.e. a perceived spatial and temporal detachment from impacts of climate change. Consequently, people tend to ascribe them to other parts of the world (e.g. islands in the South Pacific Ocean) and a distant future (Chiari et al. 2016). In a study conducted with students of German high schools, Fiene (2014) shows that adolescents predominantly believe that climate change only happens on a global scale and that they consider climate change irrelevant to their own home. Consequently, they pay scant attention to the gradual nature of climate change, whose effects are barely perceivable (Renn 2018). Furthermore, they do not feel affected, have a low sense of responsibility and little willingness to act against the impacts of climate change. Due to psychological distancing and the misguided belief that climate change is merely a global phenomenon, many people share the conviction that their opportunities for actions are very limited and that they, as individuals, cannot make a difference (Renn 2018).

\section{Inquiry-Based Learning as a Promising Approach}

Researching climate change in their own backyard through inquiry-based learning (IBL) can be an opportunity for students that may help to overcome psychological distancing as it is based on individual interests, takes place close to home and in social interaction with peers. 
In the following chapters, we will discuss potentials of inquiry-based learning for the topic of climate change in more detail. In addition, we will introduce our research project, in which students apply this very approach and summarise our experiences in a résumé.

\section{IBL as a Promising Approach for Climate Change Education}

It is obvious that there is no universal solution for the challenges of climate change education, but certain approaches seem to be particularly suitable for such settings. One exemplary approach is inquiry-based learning, which facilitates and optimises climate change education, especially with regard to the difficulties outlined above.

\section{What Is IBL?}

Inquiry-based learning is not a uniformly defined concept, but rather an array of didactic approaches that cover a wide range of educational areas and disciplines and can take different forms as well as names (Reitinger 2013; Brumann and Ohl 2019). However, all of them share a core of principal characteristics that, in light of the school context, can be described as a form of learning that aims for searching and finding insights, which are new at least to the learner, but can also be of interest to third parties. Attitudes and methods of inquiry-based learning are analogous to the fundamental mindset and approaches of scientific work (Messner 2009; Huber 2009). This means that, during their learning process, students partly or fully complete a typical scientific research cycle by developing questions and hypotheses, choosing and applying appropriate methods and then analysing, interpreting and presenting results (Huber 2009; Reitinger 2013; Pedaste et al. 2015). The goal is to apply and consequently acquire scientific core competences. These include both receptive research skills, such as information literacy, statistical literacy and critical thinking, as well as productive research skills. The latter include cognitive competences such as knowledge about research processes and methods, the generation of hypotheses or data analysis, affective-motivational competences such as research-related selfefficacy or a tolerance of uncertainty and ambiguity, and the social competence of cooperation in a learning community (Gess et al. 2017). Furthermore, IBL should at best require and encourage a so-called research attitude. According to Gess et al. (2017), this includes a reflexive distance-i.e. a reflective, questioning attitudeepistemic curiosity, in the sense of an intrinsically motivated tendency to find out new things (Kidd and Hayden 2015), as well as differentiated epistemological beliefs, i.e. the assumptions of a person about the nature of knowledge and the process of knowledge acquisition (Klopp and Stark 2016).

The range of didactic approaches, which correspond, at least in essence, to this basic character of IBL, is broad and varies in a number of dimensions. On the one 
hand, there are forms of teaching, which (for didactic and/or organisational reasons) are greatly simplified; they are pre-structured, narrowly focused and, hence, rather less scientific. On the other hand, there are approaches that can be very close to the model of scientific research, especially with an increasing age of the learners and in higher and adult education. As a rule, such concepts are only feasible as long-term projects. Their characteristics are that students work successively, on the basis of their own curiosity and questions and with a high level of self-control on complex topics that are closely connected to their everyday lives. With respect to content and methodology, the concepts align with (at times integrative) approaches from the humanities and natural science and/or humanities. Findings are then often of importance to third parties, i.e. their relevance goes beyond the individual learning processes (Brumann and Ohl 2019).

\section{Potentials: How Can IBL Face the Above Mentioned Challenges?}

There are many good reasons that argue for inquiry-based learning from an educational and scientific theoretical point of view. Also with regard to the challenges that successful education of topics relevant to sustainability, such as climate change, brings along, inquiry-based learning has considerable potential. For example, since the students are constantly asked to autonomously find, define and structure problems as well as plan, conduct and analyse investigations in communication and cooperation with other learners, IBL requires and fosters specific competences, which are highly important with regard to student's everyday lives. Moreover, the management of resources, the making of decisions and the fact that students have to be able to endure ambiguity enhances this effect further. Kuisma (2017) showed that a corresponding set of so-called "twenty-first century skills" can be promoted through inquiry-based learning. Many of these "design competences" can also be considered as important elements of education for sustainable development (ESD) (BLK Program Transfer-21 2007).

Among other things, Tilbury (2011) highlights the critical questioning of information as central to ESD. Especially in times of the internet and the concomitant complexity and controversy of available information, this is generally considered an important key skill. Relevant scientific studies have shown that inquiry-based learning has a positive effect on the ability to think critically (for example Apedoe et al. (2006) in the field of geology, or Uzunöz et al. (2018) in the sports sciences). AlMaktoumi et al. (2016) observed that students participating in a hydropedological research project in Oman adopted an increasingly critical questioning attitude. In some cases, on the basis of own experiences, this attitude even led to the questioning of common textbook knowledge. Especially in regard to science education, Duran and Dökme (2016) were able to show that IBL fosters a better development of critical thinking compared to conventional approaches. 
In addition, IBL also offers a great potential for dealing with the above-mentioned students' scientific (mis-)conceptions. In order to make use of these conceptions and to enable a Conceptual Change in the sense of constructivist learning processes (see e.g. Reinfried 2007), Schuler (2011) postulates the need for interdisciplinary and systematic learning as well as the requirement to teach students the ability to acquire knowledge by themselves and to critically question this information. In addition, education about global climate change should aim at the development of differentiated knowledge about problematic consequences, perpetrator roles and opportunities for action (Schuler 2011). Since these knowledge structures are often missing, it seems to be very important to make concrete, exemplary experiences. By the application of IBL, these experiences can possibly be produced to some degree. Because of a certain analogy between student's mental misconceptions and scientific hypotheses, which both have to be adapted or replaced when they fail through experience, this seems to be a promising approach. With the help of inquiry-based learning, students can succeed in empirically modifying the existing ideas by verifying concrete facts and scientific observations. According to this potential, Kukkonen et al. (2013) show that IBL has a positive effect on the students' perception of the greenhouse effect and the understanding of this phenomenon. More general, Chinn et al. (2013) show the potential of IBL for the promotion of Conceptual Change on the basis of selected studies and own investigations. The authors suspect that this is mainly due to the active negotiation of "evidence-theory linkages" in doing research.

Another advantage of researching a concrete-at best local—phenomenon is a potentially strong relevance to one's everyday life, which has been shown to be particularly favorable for the communication of climate issues among adolescents (Chiari et al. 2016). In doing so, IBL establishes a temporal and spatial proximity between the learner and the topic, because usually research projects are carried out in immediate vicinity to the student's own backyard. Accordingly, a special challenge of IBL is to put concrete experiences in a meaningful context with the rather abstract concept of climate change. However, if this is achieved through targeted didactic action, there is a tremendous opportunity to correspond to the general principle of meaningful global thinking. Pretorius et al. (2016) refer, for example, to the potential of IBL to apply relevant knowledge and competences on site and to reflect local challenges and opportunities. In other studies (e.g. Klein 1995), this could be identified as a necessity especially for geographic inquiry even more explicitly. Thus, access to a topic will be extended to an active and practical learning dimension, which is an important attribute of ESD (Tilbury 2011; Pretorius et al. 2016). However, this does not necessarily result in the reduction of psychological distancing, which in turn could favor an increased willingness to act, because environmental psychology has shown that people do not automatically care about proximal places and the elements, properties and qualities that constitute them (Brügger et al. 2015). Nevertheless, it is still very likely to create proximity to the object of learning through inquiry-based learning, because individual curiosity, interests and questions can be seen as the starting point of the learning processes. As a consequence, students devote themselves to these very aspects of their own immediate surroundings, which feature an exceptionally high potential of intrinsic motivation. 
According to many research findings, own observation and research foster a better understanding of scientific concepts in particular (Markaki 2014). Especially in the field of Earth Sciences, two studies by Mao et al. (1998) and Chang and Mao (1999) should be mentioned, which showed that IBL promotes a generally greater learning success in researching geosciences compared to traditional approaches. In addition, the study by Klein (1995) also showed a notable increase in learning with regard to different geographic concepts and competences-including one topic on global climate change. Moreover, Namdar (2018) designed inquiry-based activities specifically on the topic of global climate change to provide future teachers with a tool to teach these relationships. The accompanying study showed a significant improvement in their understanding of global climate change.

An elaborate expertise, however, only represents one part of the felicity conditions for climate change education. The reduction of distance and abstractness can certainly facilitate the generally difficult step from knowledge to action. However, as explained above, a number of other important factors have to be added. In the research literature evidence can be found that these factors can possibly be supported by means of inquiry-based learning. It is a great challenge for teaching to overcome fear and feelings of powerlessness in relation to climate change and to replace it with the sense of self-efficacy. Gray (2018) for example shows that research in the field of earth sciences has a positive effect on the feeling of self-efficacy expectations of future teachers. Also, Sjödahl Hammarlund et al. (2013) concluded on the basis of their research that IBL promotes participants' motivation and self-efficacy expectations. This connection may be explained by the fact that a research cycle requires the learners to deal with unexpected events, solve problems independently and overcome setbacks. Learners can gain a strong sense of efficacy in situations of that sort, if the design of the IBL allows positive experiences. Additionally, these experiences may be a potential antidote to the mass media news broadcast that overwhelmingly has a threatening character.

Furthermore, tying in with the specific interests of each target group and the often heterogeneous interests within it, contributes to the success of climate communication. Various studies have shown that IBL leads to increased motivation among learners (e.g. Tuan et al. 2005; Bayram et al. 2013). The authors explain this with the comparatively great freedom of choice learners have in IBL, in the sense that learners have the possibility to control their own learning processes and choose the topics and methods based on their interests.

Finally, the willingness to adopt climate-friendly behaviour depends on certain values: while helpfulness or benevolence seem to behave a positive effect, values that focus on individual benefits tend to have negative effects on climate-friendly behaviour (Chiari et al. 2016). As values and attitudes are generally considered to be rather difficult to change, it is also difficult to make statements regarding the effect of inquiry-based learning. However, it can at least be assumed that one essential characteristic of scientific activity and, consequently, also IBL can make a contribution: research requires cooperation and communication as well as negotiating and bridging different perspectives, while "single-fighter mentalities" often make success more difficult. 
Obviously, like any other form of learning, IBL does not per se achieve the aforementioned effects. The success of the method depends on the design of the respective concept. This includes a large number of didactic decisions, which can vary depending on the context. All in all, forms of inquiry-based learning that are very similar to science, which themselves imply a series of corresponding conceptual considerations and conditions of success, are more likely to produce the intended effects.

\section{Recent Didactic Approaches that More or Less Meet the IBL Concepts}

In light of what has been described above, it is not surprising that current educational projects on climate change include, more or less extensively, elements of inquirybased learning.

A selection of the many examples of concepts that have been published in German recently are presented here:

\section{ReKli:B}

The interdisciplinary project ReKli:B, which took place between 2012 and 2016 at the Heidelberg University of Education, aims at promoting children's and adolescents' ability to evaluate regional climate change and their willingness to act upon it. Methodically, the concept is conducted with partner schools in the form of field studies, in-depth analyses in a geo-ecological laboratory and model- and experiment based approaches. Using local examples, it aims at making the ecological interrelations of climate change as comprehensible as possible. Based on several learning modules, participating students can conduct these research activities for different topics over a course of several lessons (Siegmund et al. 2017).

\section{Climate ChangeS Cities}

With Climate ChangeS Cities by the Ruhr-University in Bochum, the Trier University and the Heidelberg University of Education a new German educational project on climate change is under way. Inspired by ReKli:B, the project's emphasis is, again, on the enhancement of crucial competences such as evaluation and judgment skills and the capacity to act, and, in terms of content, the assessment of climate-related phenomena in urban spaces. Climate ChangeS Cities is based on the IBL approach described above, as students are enabled to self-directedly conduct investigations in their living environments, such as field observations in the city and laboratory work. Additionally, here based on the "experimental algorithm", students run through different stages of inquiry. According to first observation results, Climate ChangeS Cities seems to be a promising approach (Feja et al. 2019).

\section{k.i.d.Z.21}

The University of Innsbruck developed k.i.d.Z.21 as a bi-national project in cooperation with a German school. It allows students to engage in individual subprojects, 
which can include questions on climate change from both the humanities and the sciences. Particularly noteworthy is the included five-day research stay in the Ötztal Alps, which ends the project of several months. As the effects of climate change are especially visible in mountain regions, the trip gives students the opportunity to experience the effects of climate change first hand and to investigate them independently by using geographical methods (Oberrauch et al. 2015).

\section{The Augsburg Concept as an Exemplary IBL Approach in Climate Change Education}

The examples presented above give an insight into possible designs of inquiry-based learning in connection with the topic of climate change. Almost always, the details of the concept depend on the organisational and thematic requirements of the respective educational context. Very often, time is a limiting factor, especially in more scientific forms of IBL. Consequently, finding ways to implement IBL as prototypically as possible into the given educational contexts, is particularly challenging. At Bavarian secondary schools, the so called "W-Seminare" in years 11 and 12 are a framework that offers the chance to teach propaedeutics and therefore prepare students for scientific work at universities. Over the course of one and a half years, students are enabled to develop science-related competences and a general ability to study. From the perspective of one school subject, the W-Seminars are also meant to make inquiry-based learning possible (ISB 2011). Although there are already numerous best practice examples of W-Seminar concepts, the full potential, especially with regard to the intention to give students' learning processes a clear scientific character, has not yet been exhaustively realised. Aiming at meeting both the requirements of propaedeutics and climate change education, the Chair of Geography Education at the University of Augsburg is currently developing a subproject of the Bavarian BaySICS climate research project initiated in 2018. The basic idea of the concept is to involve students, based on the concept of Citizen Science, in researching regional and local implications of global climate change in Bavaria. They use the one-and-a-halfyear period to complete a full scientific research process, which includes acquiring basic competences, finding and developing individual research questions, planning and conducting data collections, analysing, interpreting and communicating results and, eventually, writing a scientific paper (see Fig. 5.1). In the following the didactic conception of the individual phases is briefly described:

\section{Development of the Factual Basis for the Topic of Climate Change}

The introductory lessons serve to give the students an organisational overview, make a first connection between the topic and their everyday lives and arouse curiosity. Following that, students shall delve into the topic for several weeks, paying special attention to regional aspects. A modular structure, which has already proven beneficial in other projects, is used to introduce the factual basics prior to the research 


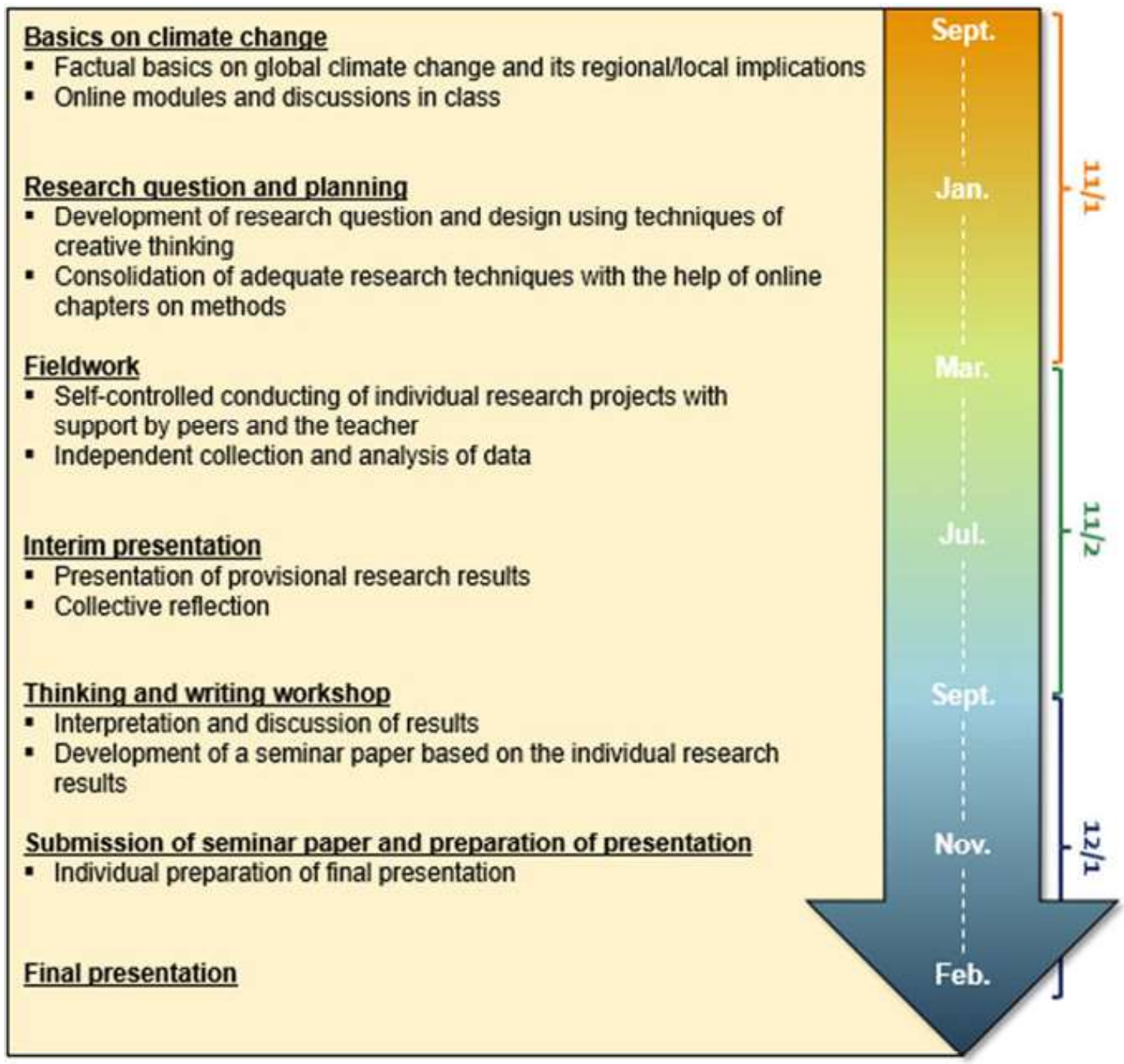

Fig. 5.1 Overview of sequences of the W-Seminar on regional/local implications of climate change in Bavaria

processes. There are several good reasons to make use of an online-based implementation: one main argument is the close relation to students' everyday lives, as most of them are confronted with online media contents on a daily basis. Therefore, it can be assumed that students not only show an affinity to such contents, but also basic technical competences in intuitively handling them.

At the same time, in contrast to analogue forms, online modules offer the chance to combine a wide range of learning materials (e.g. YouTube videos, audios, documents, hyperlinks to external databases, mapping services etc.) and thus different approaches. The Onlinekurslabor of the University of Augsburg, within which the modules have been realised, also offers the possibility of integrating a number of interactive tasks (e.g. multiple choice questions, drag and drop tasks, cloze tests) that already allow a certain amount of self-control in this first phase. As the concept is intended to be used at many different Bavarian schools, the online platform allows easy multiplication and the creation of a network for the participating schools. Additionally, a didactic system that includes current scientific findings-which are 
indispensable to a topic such as climate change-should be constantly modifiable. An online platform makes it possible to revise the content at a central point for all users.

At this point, the online course laboratory includes modules on "General basics of climate change", "Climate change perception", "Environmental protection", "Climate change and forest ecosystems", "Climate change related pollen pollution", "Phenology as an indicator of climate change" and "Climate change and tree line changes". Other modules on important anthropogeographic and physiogeographic topics are currently being developed.

\section{Development of Individual Research Questions and Planning of Data Collection}

The development of individual research questions based on personal interests plays an important role in inquiry-based learning (see Chap. 2.1). Accordingly, in a second phase of the W-Seminar, students elaborate regionally embedded research questions as well as suitable methodical designs based on their own ideas and interests that they developed earlier on closer examination of the topic. On the one hand, creative techniques can be used to help students further develop and/or narrow down their topic. On the other hand, measures of structuring, orientation and support ensure the emergence of a scientific research question. In addition, short application-oriented "how-to" chapters on climate-related research methods in the online course laboratory help students to create an optimal matching between their question and survey design.

\section{Fieldwork}

Based on the now established individual research questions, they start the actual fieldwork in their own living environments comprising the processes of searching and discovering, observing and measuring, inquiring and documenting, as well as reflecting and analysing. Regular reflective and metacognitive approaches should empower students to expand their thinking through their own inquiry as well as to address the nature of science and their own epistemic beliefs. However, in such a significantly self-controlled phase, constant individual support as well as the exchange and cooperation in the peer group play a pivotal role. This is realised in the form of regular meetings, in which central findings can be discussed. In order to satisfy these aspects in the best possible way, it is particularly important to allow sufficient time. Due to the generous time frame of the W-Seminar concept, it is possible to allocate around three months for the fieldwork.

\section{Interim Presentations}

An intermediary milestone are the presentations of the preliminary research results that take place before the summer holidays. They fulfil several functions: On the one hand, they mark a first success for the students, because by that time some data has been collected, first findings are noted and preliminary interpretations are made, which means that every student has already produced knowledge in a "raw form". On the other hand, the preparation and structuring of this knowledge also creates the potential for further mental differentiations. Furthermore, drawing up a presentation 
is, at the same time, a precursory product, which sets the ground for the subsequent learning phases. This not only serves as an orientation for the individual student, but also gives the teacher supervising information about the progress of the respective research projects. Lastly, it should also be mentioned that these presentations strengthen the students' communication skills.

\section{Scientific Writing and Thinking Workshops and Conclusion of the Seminar}

The last third of the W-Seminar focuses on the written elaboration of the individual research results in form of a term paper. Similar to the second phase of the seminar, the students should be provided with different measures of support to work out a written scientific paper comprising the necessary quality criteria. The central idea is to bring the social dimension of the acquisition of scientific knowledge into the classroom: Corresponding to symposiums, peer review procedures, interdisciplinary research projects, postgraduate programmes and the like, which characterise the scientific business as such, the students should perceive their own work as part of a knowledge-building community (see Scardamalia and Bereiter 2006). Accordingly, in this phase the individual inquiry is supplemented by regular seminar sessions with a workshop character, which primarily serve joint reflections and discussions, constructive criticism and mutual support. Besides the completion of the written term paper, the conclusive stage of the research process will be a final presentation, which gives the students the opportunity to present their results to an extended school public and to exchange ideas with interested specialists.

\section{First Insights}

The pilot stage of the seminar concept started in September 2018 with 14 students at a school in Augsburg. First experiences show that the following factors of the learning environment are relevant to successful learning:

\section{Social Interaction}

In the context of the previous activities, the role of sufficiently high proportions of social interaction became particularly obvious. This was especially evident in the first phase while working with the online learning modules. Whenever students discussed contents of the learning modules in class, a respectable learning progression and high level of motivation were apparent. Thus, several factors are potentially important: Firstly, the verbalisation of thoughts in the classroom requires a mental pre-structuring. Secondly, it could also be observed that the interrelated utterances of students and the teacher had a catalysing effect on the development of a common understanding. Thirdly, a classroom discussion establishes a particularly strong reference to everyday life. Although the learning modules were already designed with regard to the proximity of the contents to students' everyday life-e.g. by working with regional examples or tasks that aimed at the student's own experiences-in the 
vocal debriefings, students often resorted to self-selected current examples of specific local events or viral media issues. Moreover, in the context of oral interaction, it is also possible to respond specifically to aspects that arise situationally. The desire for opportunities for exchange and a compulsory backup of (intermediate) results explicitly mentioned by the students stresses the considerable potential of classroom discussions further. In contrast, stages in which students had to work autonomously with the online modules for longer periods turned out to be unfavourable in respect of progression and motivation.

\section{Interaction of the Factual and Methodical Discussion}

Especially in terms of motivation, but also in terms of the concrete comprehensibility of contextual relationships, the close interconnection of technical and methodological parts became obvious. With regard to opportunities in which students can learn about a scientific method, or in which they can exemplarily apply it, indicators for an increased curiosity and/or increased interest were observed. In addition, in such situations, the students were particularly well equipped to grasp the thematic aspects on the level of content that potentially could be explored with the respective method. On the one hand, this can be justified by the combination of procedural and declarative knowledge. On the other hand, the testing of a specialised method, such as the microscopy of pollen of nearby plants, the measurement of climate parameters in the schoolyard, or the interviewing of passers-by on campus, again establishes a relationship between scientific contents and genuine life-world situations. Accordingly, it is not surprising that those phases, which are solely based on the processing of the online modules, do not show comparable effects.

\section{Measures of Guidance}

The role of adequate measures of guidance, which has been emphasized for the success of inquiry-based learning processes by earlier studies (e.g. Lazonder and Harmsen 2016), could also be observed during the W-Seminar. Prompts and heuristics proved very useful for the learner group who had not worked in this way before and to foster students' awareness of when and how to perform certain tasks and actions. Especially in the case of specialised methods, detailed explanations were used to guide the learners step by step towards the correct application of the method. In order to allow students to focus on the contents only, the first interim presentations were scaffolded, i.e. the corresponding Power Point presentations were pre-structured on the basis of individual building blocks. Situations that lacked constraints and scaffolding turned out to be rather hindering for the learning process (for a detailed typology of IBL guidance see Lazonder and Harmsen (2016)). In general, different forms of support can be applied dynamically over the course of the seminar, as every phase of the research cycle may require specific strong control measures. However, for certain recurring inquiry skills such as communicating research results, the intensity and specificity of guidance measures can fade out successively, as students improve their competences during the course of the project. 


\section{Additional Influencing Factors}

Even though a corporate design for the materials may seem trivial, it proved to be very favourable for the perception of identity and professionalism. Additionally, a learning environment, which is tailored to the perspectives and needs of the students and ascribes the teacher the role of a mentor and learning companion, turned out to be profitable, as it entails a strong learner-orientation. Conversations with the participating students also revealed that framing the concept with the Citizen Science Approach as well as the close exchange with the university, promote the feeling of participating in a superordinate societal task and thereby a sense of responsibility.

\section{Conclusion}

So far, experience with climate change education has shown that especially the factual and ethical complexity of the field and the perceived spatial and temporal detachment are key concerns. According to research findings, inquiry-based learning seems to be a promising approach to deal with these difficulties, as it fosters (among others) selfdirected learning, critical thinking skills, the redesign of scientific misconceptions, local action on global issues, as well as the development of a feeling of proximity and perceived self-efficacy. The Augsburg IBL concept was designed to specifically fit the needs of senior class climate change education. Based on first insights, it seems suitable to achieve its intended goals. Nevertheless, important design principles that should be followed to obtain the desired results could also be identified.

\section{References}

Al-Maktoumi A, Al-Ismaily S, Kacimov A (2016) Research-based learning for undergraduate students in soil and water sciences. A case study of hydropedology in an arid-zone environment. J Geogr High Educ 40(3):321-339. https://doi.org/10.1080/03098265.2016.1140130

Apedoe XS, Walker SE, Reeves TC (2006) Integrating Inquiry-based Learning into undergraduate geology. J Geosci Educ 54(3):414-421. https://doi.org/10.5408/1089-9995-54.3.414

Bayram Z, Oskay ÖÖ, Erdem E, Özgür SD, Şen Ş (2013) Effect of inquiry based learning method on students' motivation. Procedia-Soc Behav Sci 106:988-996. https://doi.org/10.1016/j.sbspro. 2013.12.112

BLK-Programm Transfer 21 (ed) (2007) Orientierungshilfe Bildung für nachhaltige Entwicklung in der Sekundarstufe I. Begründungen, Kompetenzen, Lernangebote, Berlin. http://www.transfer21.de/daten/materialien/orientierungshilfe/orientierungshilfe_kompetenzen.pdf

Brügger A, Dessai S, Devine-Wright P, Morton TA, Pidgeon NF (2015) Psychological responses to the proximity of climate change. Nat Clim Chang 5(12):1031-1037. https://doi.org/10.1038/ nclimate 2760

Brumann S, Ohl U (2019) Forschendes Lernen im Geographieunterricht. In: Obermaier G (ed) Bayerischer Schulgeographentag 2018 Bayreuther Kontaktstudium Geographie, vol 10. Verlag Naturwissenschaftliche Gesellschaft Bayreuth e.V, Bayreuth, pp 25-41

Chang C-Y, Mao S-L (1999) Comparison of Taiwan science students' outcomes with inquirygroup versus traditional instruction. J Educ Res 92(6):340-346. https://doi.org/10.1080/ 00220679909597617 
Chiari S, Völler S, Mandl S (2016) Wie lassen sich Jugendliche für Klimathemen begeistern? Chancen und Hürden in der Klimakommunikation. GW-Unterricht 141(1):5-18. https://doi.org/ $10.1553 /$ gw-unterricht141s5

Chinn CA, Duncan RG, Dianovsky M, Rinehart R (2013) Promoting conceptual change through inquiry. In: Vosniadou $S$ (ed) International handbook of research on conceptual change, 2nd edn. Routledge, New York, pp 539-559

Duran M, Dökme I (2016) The effect of the inquiry-based learning approach on student's criticalthinking skills. EURASIA J Math Sci Technol Educ 12(12):2887-2908. https://doi.org/10.12973/ eurasia.2016.02311a

European Commission (ed) (2014) Climate change. Special eurobarometer 409. http://www.ec. europa.eu/commfrontoffice/publicopinion/archives/ebs/ebs_409_en.pdf

Feja K, Lütje S, Neumann L, Mönter L, Otto K-H, Siegmund A (2019) Climate changes citiesa project to enhance students' evaluation and action competencies concerning climate change impacts on cities. In: Leal Filho W, Lackner B, McGhie H (eds) Addressing the challenges in communicating climate change across various audiences. Springer International Publishing, Cham $(\mathrm{CH})$, pp 159-174

Felzmann D (2018) Vorstellungen von Lernenden zu Ursachen und Folgen des Klimawandels und darauf aufbauende Unterrichtskonzepte. In: Meyer C, Eberth A, Warner B (eds) Klimawandel im Unterricht. Bewusstseinsbildung für eine nachhaltige Entwicklung, Diercke, Braunschweig, pp $53-63$

Fiene C (2014) Wahrnehmung von Risiken aus dem globalen Klimawandel. Eine empirische Untersuchung in der Sekundarstufe I. Dissertation, Pädagogische Hochschule Heidelberg. https://www. opus.ph-heidelberg.de/files/47/Dissertation_Christina_Fiene.pdf

Gess C, Deicke W, Wessels I (2017) Kompetenzentwicklung durch Forschendes Lernen. In: Mieg HA, Lehmann J (eds) Forschendes Lernen. Wie die Lehre in Universität und Fachhochschule erneuert werden kann. Campus Verlag, Frankfurt, pp 80-90

Gray K (2018) Assessing gains in science teaching self-efficacy after completing an inquiry-based earth science course. J Geosci Educ 65(1):60-71. https://doi.org/10.5408/14-022.1

Huber L (2009) Warum Forschendes Lernen nötig und möglich ist. In: Huber L, Hellmer J, Schneider F (eds) Forschendes Lernen im Studium. Aktuelle Konzepte und Erfahrungen, (Motivierendes Lehren und Lernen in Hochschulen), vol 10. UVW Univ.-Verl. Webler, Bielefeld, pp 9-36

ISB/ Staatsinstitut für Schulqualität und Bildungsforschung (2011) Wissenschaftspropädeutisches Arbeiten im W-Seminar. Grundlagen-Chancen-Herausforderungen, 1st edn. München

Kidd C, Hayden BY (2015) The psychology and neuroscience of curiosity. Neuron 88(3):449-460. https://doi.org/10.1016/j.neuron.2015.09.010

Klein P (1995) Using inquiry to enhance the learning and appreciation of geography. J Geogr 94(2):358-367. https://doi.org/10.1080/00221349508979744

Klopp E, Stark R (2016) Persönliche Epistemologien—Elemente wissenschaftlicher Kompetenz. In: Mayer A-K, Rosman T (eds) Denken über Wissen und Wissenschaft. Epistemologische Überzeugungen, Pabst Science Publishers, Lengerich, pp 40-70

Kuisma M (2017) Narratives of inquiry learning in middle-school geographic inquiry class. Int Res Geogr Environ Educ 27(1):85-98. https://doi.org/10.1080/10382046.2017.1285137

Kukkonen JE, Kärkkäinen S, Dillon P, Keinonen T (2013) The effects of scaffolded simulationbased inquiry learning on fifth-graders' representations of the greenhouse effect. Int J Sci Educ 36(3):406-424. https://doi.org/10.1080/09500693.2013.782452

Lazonder AW, Harmsen R (2016) Meta-analysis of inquiry-based learning: effects of guidance. Rev Educ Res 86(3):681-718. https://doi.org/10.3102/0034654315627366

Mao S-L, Chang C-Y, Barufaldi JP (1998) Inquiry teaching and its effects on secondary-school students' learning of earth science concepts. J Geosci Educ 46(4):363-367. https://doi.org/10. 5408/1089-9995-46.4.363

Markaki V (2014) Environmental education through inquiry and technology. Sci Educ Int 25(1):8692 
Messner R (2009) Forschendes Lernen aus pädagogischer Sicht. In: Messner R (ed) Schule forscht. Ansätze und Methoden zum forschenden Lernen. Körber-Stiftung, Hamburg, pp 15-30

Meyer C, Eberth A, Warner B (2018) Einführung. In: Meyer C, Eberth A, Warner B (eds) Klimawandel im Unterricht. Bewusstseinsbildung für eine nachhaltige Entwicklung, Diercke, Braunschweig, pp 4-5

Namdar B (2018) Teaching global climate change to pre-service middle school teachers through inquiry activities. Res Sci Technol Educ 12(2):1-23. https://doi.org/10.1080/02635143.2017. 1420643

Oberrauch A, Keller L, Riede M, Mark S, Kuthe A, Körfgen A, Stötter J (2015) k.i.d.Z.21— kompetent in die Zukunft-Grundlagen und Konzept einer Forschungs-Bildungs-Kooperation zur Bewältigung der Herausforderungen des Klimawandels im 21. Jahrhundert. GW-Unterricht 139(3):19-31

Pedaste M, Mäeots M, Siiman LA, de Jong T, van Riesen SAN, Kamp ET, Manoli CC, Zacharia ZC, Tsourlidaki E (2015) Phases of inquiry-based learning: definitions and the inquiry cycle. Educ Res Rev 14:47-61. https://doi.org/10.1016/j.edurev.2015.02.003

Pretorius R, Lombard A, Khotoo A (2016) Adding value to education for sustainability in Africa with inquiry-based approaches in open and distance learning. Int J Sustain High Educ 17(2):167187. https://doi.org/10.1108/IJSHE-07-2014-0110

Ranney MA, Clark D (2016) Climate change conceptual change: scientific information can transform attitudes. Top Cogn Sci 8(1):49-75. https://doi.org/10.1111/tops.12187

Reinfried S (2007) Alltagsvorstellungen und Lernen im Fach Geographie. Zur Bedeutung der konstruktivistischen Lehr-Lerntheorie am Beispiel des Conceptual Change. Geographie Schule 168:19-28

Reinfried S, Tempelmann S (2014) Wie Vorwissen die Lernenden beeinflusst-Eine Lernprozessstudie zur Wissenskonstruktion des Treibhauseffekt-Konzepts. Zeitschrift für Geographiedidaktik 42(1):31-56

Reitinger J (2013) Forschendes Lernen. Theorie, Evaluation und Praxis in naturwissenschaftlichen Lernarrangements (Theorie und Praxis der Schulpädagogik), vol 12, 2nd edn. Prolog-Verlag, Immenhausen

Renn O (2018) Klimaveränderungen als systemisches Risiko erkennen-Wege zur Handlungsbereitschaft. In: Meyer C, Eberth A, Warner B (eds) Klimawandel im Unterricht. Bewusstseinsbildung für eine nachhaltige Entwicklung, Diercke, Braunschweig, pp 77-85

Scardamalia M, Bereiter C (2006) Knowledge building: theory, pedagogy, and technology. In: Sawyer RK (ed) The Cambridge handbook of the learning sciences (1. publ). Cambridge University Press, Cambridge, pp 97-118

Schuler S (2011) Alltagstheorien zu den Ursachen und Folgen des globalen Klimawandels. Erhebung und Analyse von Schülervorstellungen aus geographiedidaktischer Perspektive (Bochumer Geographische Arbeiten), vol 78. Europäischer Univ.-Verl, Bochum

Siegmund A, Brockmüller S, Schuler C, Volz D (2017) Regionalen Klimawandel beurteilen lernen-interdisziplinärer Ansatz schulischer und außerschulischer Umweltbildung am Beispiel des UNESCO Geo-Naturparks Bergstraße-Odenwald. Abschlussbericht des Umweltbildungsprojekts. Deutsche Bundesstiftung Umwelt, Heidelberg. https://www.dbu.de/OPAC/ab/DBUAbschlussbericht-AZ-29231.pdf

Sjödahl Hammarlund C, Nordmark E, Gummesson C (2013) Integrating theory and practice by self-directed inquiry-based learning? A pilot study. Eur J Physiother 15(4):225-230. https://doi. org/10.3109/21679169.2013.836565

Tilbury D (2011) Education for a sustainable development: an expert review of processes and learning. UNESCO, Paris

Tuan H-L, Chin C-C, Tsai C-C, Cheng S-F (2005) Investigating the effectiveness of inquiry instruction on the motivation of different learning styles students. Int J Sci Math Educ 3(4):541-566. https://doi.org/10.1007/s10763-004-6827-8

Uzunöz S, Erturan Ilker G, Arslan Y, Demirhan G (2018) The effect of different teaching styles on critical thinking and achievement goals of prospective teachers. Spormetre 17(2):80-95 